\title{
A FREE INSIGHT ABOUT USING SMARTNESS LAW IN INTERNAL AND EXTERNAL ARCHITECTURE
}

\author{
Maryam Ghaleh Golab \\ Azad University of Tehran \\ mghalehgolab@gmail.com \\ Amir Masoud Dabagh \\ Azad University of Tehran \\ amirmasoud dabagh@yahoo.com
}

\begin{abstract}
In every science we confront with several branches and trends. As if we have seen fragmentation of every subject best way of examining it. Although initially dividing each subject into its elements is very effective to understand it but finally to exploiting it practically and functionally again we have to go to its whole. And traditional medicines and thousands of other models to reach internal calm of human while every one can build this calm with his/her internal architect.
\end{abstract}

Keywords: free insight, smartness law, external and internal architecture

\section{İÇ VE DIŞ MIMARLIKTA SERBEST MEKANI AKILLI KANUNLA KULLANMA}

ÖZ

Bu çalışmada, serbest mekanın kullanımına özgü bir durum değerlendirmesi yapılmaktadır. Mimaride iç ve dış mekanın akıllı kanunla kullanımı araştırma konusudur. Bireylerin içi ve dış mekan mimarisinde serbest mekan olgusunu kullanma ve üretme biçimleri çalışmada sorgulanmaktadır.

Anahtar kelimeler: serbest mekan, akıllı kanun, iç ve dış mimari

\section{INTRODUCTION}

In every science we confront with several branches and trends. As if we have seen fragmentation of every subject best way of examining it. Although initially dividing each subject into its elements is very effective to understand it but finally to exploiting it practically and functionally again we have to go to its whole. Our mistake is exactly the point that we have ignored that the sciences that we have gathered during years all are elements of a whole set, in medicine, we use specialists of skin, ear, to surgeo of heart, brain ... and sciences such as Chakra therapy, energy therapy... And traditional medicines and thousands of other models to reach internal calm of human while every one can build this calm with his/her internal architect.

We have entered this method into everything even architect and have created different architect-wise styles and traditions and we have been left from final goal that is human calm and from this paper authors view establishing various trends is just for satisfying human kind diversity sense. We must know as no finger print is like as the other finger print and no snowflake isn't like the other, creation of this styles and models has no end and we will reach to new style by moving them.

Then why we amuse ourselves and escape from the main issue? That is, designing harmonization of human interior and exterior according only existence law is so difficult that we branch it? In the 
author' belief if we are really human and are proud of it so we must take the entire story and don't pursue endless entertainments. The general law of existence is the same smartness law that using it needs change of human insight filter that we will explain it in the article.

\section{ISSUE EXPLANATION}

Our today architect needs human body and soul, now it's the time that we after identifying physic and metaphysic world avoid from ascribing their roots to other titles and designing by various procedures and styles and see all of them form a single view to reach a single goal and architecture of our internal emotions and external space doesn't disrupt this calm.

Also to change existence laws it is necessary to change human insight forms because not only for many it is new but also for many is unacceptable and in this article it has been attempted that by showing some examples we speak form this valuable law to each one of us can be ourselves life because every one is best architect of his/herself.

Maybe the greatest sin of human is that leave the world without identifying the governing law on the existence. Now architects task get particular importance because they are among people that with knowledge and applying it can design external architecture according existing world such that it would be guide and a training way for all people. Now the question arises that how we have a free insight? How we understand smartness law? And how do our internal and external architecture?

\section{RESEARCH NECESSITY}

Establishing a society different from what we have experienced up to now as today our scientists have realized truly role of emotions in human life formation. Humans must live such that their external space adjusts with their internal existence and emotions. With these changes we can break our closed environments that we have built in our surrounding and live within them because these closed environments initially form in people interior and gradually emerge their appearance in people external environment.

1) Of course architects, from another point of view that I would like to present, can show to people that impossibilities that they build in their minds all are feasible and would be like a teacher that illustrate their task and attitude to whole society and be their guidance to build their life.

2) it acts like the law governing the existence world such that is available and testable for everyone, providing we like to change our attitude into existence world and if began and find exact statistics, it is predictable that future generations will know and use it more easily and definitely people having a different attitude to life also need a different architecture.

Then in every case if consider unaware people, an architect know it necessary that with his designs instruct humans according their real existence that what is true pleasure of life? And also provide an environment to knowledgeable people can continue life in coordination with their existence.

\section{THEORETICAL BASES}

All of us while designing have experienced this sense that our feelings is boiling and something move in our mind and this just get in a clean and empty form psychological violence. This architecture training must increase in all society so that all people have the ability of using the valuable law in their interior and its consequences can be used in macro-level.

This paper content is based on that some spark must be struck that we awake and wouldn't be captive of last and present generation's destructive thoughts and modify the information that have been given to our insight filter, and don't let believe in impossibilities imprison us and prevent our creativity or don't let any instance hurt us. To further explanation of this subject we define "insight filter" of human that has been formed from institutionalized information of child age and influence from acceptable information in adulthood. 
For example, if some people are in a hall and suddenly, a tremendous explosion voce is heard, each of audiences will have a different reaction to the other. Now assume that one hour after the explosion, another one would occur, suddenly our reaction will change and accordingly will be more weak or strong. One solution to change this insight by our will is that before issuing initial order to brain, we can plan correct orders in insight filter section, so that events couldn't abrupt chemical balance of brain. Human live in senses world but due to partitioning his/her knowledge in small scale, isn't able to have a correct conclusion of the subject, make right decision and undertake great works, as if have restricted himself to his previous insight filter toward existence world and as a result has failure in this insight that his abilities has no limit tanks to smartness law.

\section{SMARTNESS LAW DEFINITION}

In smartness law, thought is born of consciousness and intelligence that act in two forms: first, in the form of consciousness with good selection of thinker and decision maker, second, in the form of obedient consciousness performing orders of innovative consciousness. But in case that human look isn't coinciding to truth and judge events, he would involve in internal and external conflicts and because of its resulting psychological pressures will suffer from several diseases.

Thinkers can see this valuable law in the state of particles absorption and rejection. Einstein believed that there are undeniable evidences of order in the world law that they are the same consciousness governing on the existence world and in this case Jinz, Edingtone, Milikon and other leading physicists think like him (Fredrik Bilz, 1994: 24).

As poets like William Shakespeare, Robert Broning and William Blake in their poems and musicians like Ludwig van Beethoven in their music have reminded it. Artists such as Leonardo Da vinci have drawn it in their paintings and leading thinkers such as Socrates, Plato, Rolf Valdo Emerson, Pythagoras, Sir Francis Bacon, Isaac Newton, Yohan Wolfgang von Goethe and Victor Hogue have mentioned it in their teachings and their names have been remained for centuries and their epic works is eternal (Randa Bern, 2007: 14).

The knowledge we speak about is somehow human's main language to his peripheral environment, likely everyone has experienced this issue well. For example, if we sit some minutes beside a depressed person, without saying anything, we also feel sad and on the contrary; when confronting with some people we feel calm and with the others, feel anxiety and this human's main language i.e. radiation language.

Now your life is reflection of your last thoughts that it contains all good and bad things of your life, even if all people of the world realize the fact of smartness law in the world and uses this power in maximum degree, a bit doesn't deduce of it. But never it present or impose its services and await to be identified, it is required that human himself realize that have such powerful companion that can or desire to get his to whished position. So, this power there isn't until human know and use it (Fredrick Bilz, 1994: 132).

\section{SMARTNESS LAW IN DIFFERENT RELIGIONS}

There are many evidences throughout history of treatment without intervention of a tool and material elements that confirm this claim. In Torah has been mentioned that Israelites to treat snakebite, put the snakebited person in front of a charismatic bronze snake and he was treated by staring to it, his is a type of mental treatment by alike under which they treated the same material with the same material, something that no one doesn't dare today. History has documented exact details of mental treatment by alike by Moses. Psychological and mental treatment may use material elements to obtain goal or not but it isn't dependent on them, in Torah there are many instances of psychological and mental treatment; Elisha Elijah Danil and many prophets were healer in the past time that used it as a miracle. Then Jesus appeared, he believed that all diseases is result of human internal and psychological state disruption and showed that its cure is correcting the hidden state that by correcting it all disease disappear. Here we have to mention that today physicians attempt to apply correcting individuals' 
unbalanced mental state that is main cause of diseases. Jesus had to wait two thousands and some years to detections formalize his teachings (Fredric Bilz, 19994: 97).

\section{MEDICAL INSTANCES}

Belief has a significant role in use of this law, and it doesn't construct on doubt. Test of healing law to start a firm belief is available to all and clearly confirms its claim. Table 1 presents instances of emergence of three various treatments in different era of human life that each one have endured many difficulties to approve demonstrate themselves in society. They individually presented a treatment way different from their predecessors that resulted in healing as well and in the point of the author reaching to treatments just were dependent on their belief power.

Table 1. Detected instances

\begin{tabular}{|c|c|l|l|}
\hline year & $\begin{array}{c}\text { Physician } \\
\text { name }\end{array}$ & $\begin{array}{l}\text { Medicine } \\
\text { detected }\end{array}$ & Treatment method \\
\hline 1796 & $\begin{array}{c}\text { Samouel } \\
\text { Hahni man }\end{array}$ & Homeopathy & $\begin{array}{l}\text { Very little amount of drug, has more effect than its } \\
\text { much amount. } \\
\text { Treatment with alike, the signs existing in patient and } \\
\text { drug material, be alike as much as possible. }\end{array}$ \\
\hline 1874 & Andrid Steel & $\begin{array}{l}\text { A method by } \\
\text { massage }\end{array}$ & $\begin{array}{l}\text { All internal organs are recovered and patient is } \\
\text { treated without drug use. }\end{array}$ \\
\hline 1895 & Didi- Palmer & Chiropractor & $\begin{array}{l}\text { Neurology science school, all diseases are created } \\
\text { because of nerves collision with spinal cord }\end{array}$ \\
\hline
\end{tabular}

These different methods in treatment are evidence for the claim that beyond all these must there is another factor to return health to patient, in fact each of them helped patient to accept that will be treated, each of these methods just would be acceptable for patient until after a spark in his mind, result is obtained. Like oil wells that are drilled by different companies and finally all reach to a main resource. Now we are presented with some instances of real healing through this method by contemporary physicians that a few of them are presented in table 2.

Table 2. Real treatments in current age

\begin{tabular}{|l|l|l|l|l|}
\hline Physician & place & Disease & Treatment method Disease reason \\
\hline Abraham Mirson & Boston & $\begin{array}{l}\text { Ulcers, Asthma, } \\
\text { skin and heart } \\
\text { disease, Anemia, } \\
\text { indigestion }\end{array}$ & $\begin{array}{l}\text { Result of psychological illnesses and } \\
\text { turbulent emotions and their effect } \\
\text { disappear when they are treated mentally. }\end{array}$ \\
\hline Lion, G. sall & Chicago & Cold & $\begin{array}{l}\text { Desire of reaching to something and } \\
\text { failure, by considering the persons } \\
\text { succeeded }\end{array}$ \\
\hline Julius, Himan & New York & $\begin{array}{l}\text { Sinusitis, nose } \\
\text { Polyps, } \\
\text { inflammation and andect by negative idea cause secretions } \\
\text { nervous states }\end{array}$ & $\begin{array}{l}\text { Affected } \\
\text { intures and return again by surgery and } \\
\text { medicine use, their healing method is } \\
\text { change of thinking way }\end{array}$ \\
\hline
\end{tabular}

Now many people have experienced and tested this law, it is several decades that human body polarity area map has been developed in one of U.S.A universities and today this field is instructed as "energy therapy" in different universities of the world. The area that is about human and cell is the abovementioned human radiation language.

\section{ARCHITECTURE INSTANCES}

As in medicine we have involved ourselves in different trends and established law, in architecture also the problem has been occurred and we have involved ourselves in different styles for design and get away from existence main law and its final goal - human calm. Rare instances of using this law have been remained in construction of architecture works from ancient era that, unfortunately, because we 
have separated ourselves from this law, call them wonders. If our predecessors would return and see our architecture and life style, they would call us with an more strange than wonders because in the author's opinion disease is a strange thing for a future generation that plan their life based on this law, our future generations can live with truth and reach to calm under which.

Table 3. architecture instances (source: Hanse Rishhart, 2008)

\begin{tabular}{|c|c|c|}
\hline Building (wonders) & Year of construct & Constructor \\
\hline Great Pyramid of Giza & 2584-2561 B.C & Ancient Egypt \\
\hline Hanging Gardens of Babylon & About 600 B.C & Babylon civilization \\
\hline Temple of Artemis & 550 B.C. & $\begin{array}{l}\text { Lidieh, Hakhamanesian, } \\
\text { Ancient Greece }\end{array}$ \\
\hline Statue of Zeus at Olympia & $\begin{array}{c}\text { 466-456 B.C. (temple) } 435 \\
\text { B.C. (statue) }\end{array}$ & Ancient Greece \\
\hline Holly Cemetery Karnasvs & 351 B.C & $\begin{array}{c}\text { Cariaeeha, Solookieh, ancient } \\
\text { Greece }\end{array}$ \\
\hline The Colossus of Rhodes & 292-280 B.C. & Ancient Greece \\
\hline Lighthouse of Alexandria & 280 B.C. & $\begin{array}{c}\text { Hellenistic Egypt, ancient } \\
\text { Greece }\end{array}$ \\
\hline
\end{tabular}

"Bob Praker: wise people always were aware of this isse. You can just now go to ancient Babylonians. They now always this law. This is selection of a small group of people". Ancient Babylonians civilization and creating hanging gardens, is famous as a one of the Even Wonders of the world. This people through understanding and application of universe laws were one of the richest races during human history (Randa Bern, 2007:14).

But today we have gone back in architecture unlike medicine and instead of a holistic attitude to existence law, have substituted it with reductionism and creating various styles and involved ourselves in criticizing and examining them. In architecture universities instead of correct teaching of architecture, based on smartness law, just we have amused with margins. Table below presents some instances of styles created in recent decades.

Table 4. Architecture styles in recent decades

\begin{tabular}{|c|c|c|c|}
\hline $\begin{array}{c}\text { Style } \\
\text { Modern } \\
\text { architecture }\end{array}$ & idea & Suggested by & year \\
\hline $\begin{array}{c}\text { Modern } \\
\text { architecture }\end{array}$ & Ornament is a crime & Adolph Louse & 1926 \\
\hline $\begin{array}{c}\text { Modern } \\
\text { architecture }\end{array}$ & A house is machine for living & Corbozie & 1910 \\
\hline $\begin{array}{c}\text { Modern } \\
\text { architecture }\end{array}$ & Less is more & Miss Vendro & 1949 \\
\hline Post modern & Less is a bore & Robert Venturi & 1962 \\
\hline Post modern & Moore is more & Charlz Moor & 1978 \\
\hline Hi-tech & $\begin{array}{c}\text { In the modern age,we should } \\
\text { live in modern buildings }\end{array}$ & Richard Rogers & 1971 \\
\hline Neoclassic & Spirit of all times & Rob Crier & 1984 \\
\hline Deconstruction & presentness & Peter Aizenmen & 1982 \\
\hline
\end{tabular}




\begin{tabular}{|c|c|c|c|}
\hline Folding & Weak form & Peter Aizenmen & 1990 \\
\hline $\begin{array}{c}\text { Universe } \\
\text { appearance }\end{array}$ & More is different & Philip Anderson & 1996 \\
\hline
\end{tabular}

\section{IMPACT OF SMARTNESS LAW ON CREATIVITY}

The author doesn't intend in this article to criticize architecture, her only objective is addressing to a story about human and their real life. Always running away to fantasy world is pleasant providing that we don't see them just in dream and know that they will be realized. In one hand, it can be said that base of all sciences is inspirations, i.e. the human mental spark and provide encountering with new knowledge for individual. That is, common feature of all mental sparks - awareness receive - that can occurs in a fraction of a second. Architecturally it can be explained that by appearance of a mental image, a new line of visualization is formed. Then whole design changes and in a fraction of a second, is formed again. As if a powerful forces from outside suddenly effect us. With these inspirations, everything that is previously about a thing is creating, illuminate in our mind rays, and find a new shine and a deep pleasure and enthusiasm reveal in our interior that show "our desire space" has been formed.

I don't claim that know what is exactly the space and more think about that, it becomes more mysterious for me but I have confidence that we are related to space as architecture, when we deal with an extreme small part of infinity, every space have assigned a particular space in this infinity to itself. How these statues and molds a part of internal space from its peripheral can be separated can be very magical. They embrace a mysterious void called space with a special way and make it tangible.

Based on this fact, the deepest joys of life are in human adaptation with its radiation thoughts. Humans with unifying their thought and acts, will experience highest level of welfare, we must can find a sense presence that is always with us and through which design a new environment which contain all that is named magic in itself. We shouldn't forget that this magic has been blown in our bodies individually and has filled us with a power that can move a mountain and this is the same magic of will, perseverance charm and enjoyment of a mysterious power like love and hope by which we venture into extraordinary actions that are much more valuable, glorious and viable than mythological magic in stories. The article objective is only introducing the law an encouraging people to apply and preserve it. In the following it has been attempted that a small section of creativity is presented that we can have after knowing this law:

Table 5: creativity in architecture with smartness law (source: Joulia Cameron, 1998)

Basic principles of creativity considering smartness law

Creativity is natural order of life. Life is energy: pure creative energy

Hidden creativity power makes rich all life - including us.

When we expose ourselves to creativity, we expose to creativity of a creator that is our life.

We create ourselves. As a result, it is destined that by creativity continue creativity.

Creativity is God gift to us. Using our creativity we can present this gift to God.

Of we don't be creative; we have behaved unlike our real nature, and have applied our personal will.

When we expose ourselves to detect our creativity, we expose ourselves to God - good order path.

When we open our contact way with creator, must expect powerful and fine changes.

Exposing self to a much more great creativity, is safe and has no risk.

Our creative dreams and whishes come from source. When we step toward our dreams, we

move to ourselves divine.

The concept of what was said is so exciting that can stop our heart beat. Later, when we reach to way of harmonizing ourselves with this consciousness, we will notice that how little human can orient and direct the power that operate the world. This point although is surprising but is a truth and mentalspiritual healing is it a result. But it isn't result of human little efforts but is result of his ability to

Submit Date: 10.02.2016, Acceptance Date: 25.03.2016, DOI NO: 10.7456/1060ASE/017 
direct the world consciousness, just as a welder direct a Acetylene flame to cut steel toward it, because without the flame it cant cut (Fredrick Bilz, 1994: 79-80).

\section{PERFORMANCE LIMITATION}

After detection of polarity area in America, the name of polarity therapy; Energy therapy or power therapy became common throughout the world and scholars found that one reasons for human disease could be disruption in body polarity, maybe conditions that have been occurred in human life have caused disruption of a series of environmental balances and have provided some contaminants for human. In fact, we are always affected by magnetic fields and other sky fields that are among them:

- Polarity contamination of one of power fields about human and cell - due to a metal presence in human life. Polarity contamination due to impact of electricity current on human life.

- Waves contamination that is related to increase use of different wavelengths such as communications and etc.

- Directive contaminations due to insulate and synthetic materials that cut ionic and electronic exchanges between human body and earth, such as socks or shoes.

- Impact of heavenly bodies that each has a magnetic field like earth and we are affected of them.

We are in the beginning of the truth path and must be able to design a utopia in which ourselves and our future generations can live by real structure of human and full awareness of what we are, and don't make ourselves captive for such statements as "never has been done before".

\section{FINDINGS}

By awareness of environment radiation contaminations and a view to use of smartness law we encounter with a new challenges in today architecture that either cause more development of human kind and embrace future generations also beautifully or results in a radiation fight and make life difficult for everyone. Because future generations will be raised with more awareness than us and touch the world in other way. Generally it can be said:

1) In future life disease is greatest miracle of life because of negation of existence law and human health is most natural thing in his life. Because every problem that human endure, just he is himself that has created this bondage.

2) Coded words of the new worlds are: "we are what we think". "Everything we imagine, we can obtain" (Bilz, 1994: 60). In smartness law, our task simply is selection and harmonizing with its current.

3) One use correctly existence laws, can live in entire "time and place" and reach to a higher calm than a common individual that it is the main goal of life.

4) The era on this glorious planet is most exciting era of human history. We are witnessing the impossible are possible and in the field of human endeavor and in every area experience it.

5) World hasn't seen the life possibilities by which importance of smartness law can be understood completely, and it is our tasks that as architecture convey it simply to next generations.

6) As Edison detected electricity and after that changes was began in future generations structure, we can have a dramatic change in urban and building architecture, of course after our consciousness architecture.

Dr. John Hegelin: "I see a future of limitless potential power and infinite capabilities. Remind that humans just use maximum 5 percent of their mental power. 100 percent of human potential power is 
result of correct training. Imagine a world that people use their all mental and spiritual power. In this case we can get everywhere. We can do everything. We can reach everything". (Randa Bern. 2007: 210-211).

Architecture, like practical mysticism, goes through experiencing and shouldn't be restricted to its heart beliefs. Feelings, priorities, enthusiasms and desires that appear and need formation must be occur with a constant relation between sense and logic, as it is possible that in one society all people don't want to accept such a change in their insight filter and our responsibility is just informing them and don't want to command them dictatorially to live this way.

\section{CONCLUSION}

Considering the issues discussed in this study it can be said generally and shortly that the base of architecture we pursue is shaped on sense and intuition in the form of insight into radiation worlds, of course valuable moments of intuition are result of patiently attempt.

\section{REFERENCES}

Bilz, Fredricl (1994), Seek healing inside yourself, Fakhteh press, translated by Napelon Bilow

Bern, Randa (2007), Secret, Tehran: Liosa, translated by Nafiseh Motakef

Camero, Joulia (1998), Artist Way, Peykan press, translated by Giti Khoshdel

Ghobadian, Vahid (1956), bases and concepts of contemporary western architecture, Tehran: cultural studies office

Haneh Man, Samouel (2008), Medicine Organ, Soroush press, translated by Ahmad Arjmand

Palasma, Youhani (2014), Eyes of architecture skin and sense perceptions, Parham Naghsh press, translated by Ramin Ghods

Richehart, Hans (2008), Seven wonders of the world, Ghadiani press corporation, translated by Behrooz Baghaee

Zoomtor, Peter, (1943), Phenomenological approach to Peter Zomtor's thought, Tehran: Royal architecture science, translated and gathered by Morteza Nik Fetrat, Seyyedeh Sedigheh Nirgozar Langroodi 